\title{
A ironia, a paródia e o riso como elementos de crítica social na dança brasileira de origem africana
}

The irony and parody and laughter as critical social elements in the Brazilian dance of African origin

Maria de Lurdes Barros da Paixão ${ }^{1}$ Maria Consuelo Oliveira Santos ${ }^{2}$ 


\section{Resumo}

A proposta deste artigo é estabelecer a inter-relação entre corpo, performance e antropologia através da análise de criações cênicas de intérpretes-criadores que se fundamentam em referências de origem africana e cuja proposta é a desconstrução de parâmetros que estereotipam realidades socioculturais do contexto nacional. Através de suas performances se observam elementos de crítica social e também apresentação de novas configurações para tratar temáticas afro-brasileiras. $O$ riso, a paródia e a ironia, elementos bastante ressaltados na estética pós-moderna, são utilizados nas obras O Samba do Crioulo Doido, Xirê Obirikiti e Bordados de Corpos, como elementos que possibilitam a reflexão e desconstrução das temáticas corpo-negro-exportação, erotismo, sexualidade, opressão, contestação, transgressão, etc., através de performances subversivas corporais e cênicas.

Palavras-chave: Corpo; performance; riso; ironia; paródia.

\section{Abstract}

The purpose of this article is to establish the interrelationship between body, performance and anthropology by analyzing scenic creations of performers-creators that are based on references of African origin and whose purpose is the deconstruction of parameters that producing stereotypes of social and cultural realities of the national context. Through their performances elements of social criticism are contemplated and also the presentation of new settings treating African-Brazilian themes. The laughter, parody and irony, elements quite emphasized in postmodern aesthetics, are used in the works O Samba do Criolu Doido, Xirê Obirikiti and Bordados de Corpos, as elements that allow reflection and deconstruction of thematic body-black-export, eroticism, sexuality, oppression, protest, transgression, etc., through body and performing subversive performances.

Keywords: Body; performance; laughter; irony; parody

ISSN: 1414.5731

E-ISSN: 2358.6958

\footnotetext{
${ }^{1}$ Profa. Dra. Adjunta IV do Departamento de Artes da Universidade Federal do Rio Grande do Norte (UFRN). Iuluacaso@gmail.com

${ }^{2}$ Doutorado em Antropologia Social e Cultural, Universitat Autònoma de Barcelona, (UAB). Investigadora dos Núcleos Kàwé e de Estudos do Envelhecimento, UESC (Bahia), e do Grupo Transdisciplinario de Investigación, UANL, México. consol.oliveira@gmail.com
} 


\section{Introdução}

Diferentemente da metáfora ou da metonímia, a ironia tem arestas; diferentemente da incongruência ou justaposição, a ironia consegue deixar as pessoas irritadas; diferentemente do paradoxo, a ironia decididamente tem os nervos à flor da pele. Enquanto ela pode vir a existir através do jogo semântico decisório entre o declarado e o não declarado, a ironia é um modo de discurso que tem "peso", no sentido de ser assimétrica, desequilibrada em favor do silencioso e do não dito.

(Linda Hutcheon, 2000, p. 63)

A articulação entre performance e corpo, dois temas bastante discutidos na agenda social, e com grande destaque na antropologia, nos permite estabelecer inter-relações profícuas em um momento de reconhecimento sobre as muitas possibilidades, interconexões, imbricações entre os conhecimentos. Tanto o corpo como a performance são temas que se relacionam diretamente com a escenificação (criação cênica) corporal seja no teatro, na dança, nas performances de rua ou nos rituais de grupos culturais.

É por demais sabido que a noção de performance não apresenta um consenso e nos encaminha para uma proliferação de sentidos, de sinônimos e suas diversas aplicações, seja em rituais, festas, interpretações cotidianas, música, dança, esporte, movimentos sociais e outros. Entretanto, a maioria dos conceitos concorda que seja um tipo particular de evento, em determinado cenário e perante uma audiência.

A relação entre corpo e performance tem sido um convite sempre aberto para as discussões em torno do tema e que, no âmbito da antropologia, não se pode passar ao largo das últimas obras de Victor Turner $(1982,1987)$, escritos referenciais para a antropologia da performance e, segundo o próprio autor, é parte da antropologia da experiência. A performance em Turner está alicerçada no drama, como analogia da vida social, estabelecendo uma ligação entre o ritual e o teatro, trajetória que contou com as considerações de Richard Schechner ao final da década de 1970.

Em seus estudos sobre a performance, Richard Schechner (2006) dá ênfase à relação de performer e audiência incidindo em atividades que são reelaboradas e reproduzidas ao longo do tempo. Um processo de aprendizagem por meio de exercícios repetitivos. Podem ser transferidas, apropriadas, modificadas em sequências de condutas (strips of behavior) através de ações repetidas que o autor intitula de twice-behaved behavior. Desse modo, noções da antropologia dialogam com a perspectiva teatral e vice versa, fortalecendo ambos os campos de conhecimentos.

Igualmente é uma temática que nos encaminha à noção de ritual, cuja performance corporal é significativa nas vivências ritualísticas. Para Tambiah (1968) o rito é um ato performativo que tem força persuasiva, observado em rituais de cura de grupos religiosos, por exemplo, em que a dança faz parte do próprio ritual e é considerada como um dos elementos intrínsecos à força do rito.

A literatura antropológica é pródiga em exemplos que demonstram que a cura recebe grande influência das performances rituais, isso porque a coletividade performatiza cerimônias ritualísticas que congregam forças de união, do compartilhar, do participar da dor do outro e do apoio grupal. Os ritos são expressos através de uma estética profícua em que os sentidos e os símbolos são vividos mediante sentimentos 
e sensibilidades na união de corpos que dançam para estabelecer a interconexão da pessoa consigo mesma, com a coletividade e com a vida.

Nesta trilha, ao falar de corpo é pertinente destacar que o filósofo Nietzsche (1997, 1997b) foi um dos primeiros a nos alertar para a "má" compreensão da filosofia que exaltava o espírito em detrimento do corpo. Jara (1998, p. 61) destaca que "[...] el cuerpo es el punto de apoyo para Nietzsche y el lugar de la separación de las aguas de su pensamiento con respecto al de la tradición".

Não podemos esquecer que Nietzsche foi um dos pensadores que criticaram fortemente paradigmas disjuntivos no âmbito da modernidade. Chamou especial atenção para a necessidade de se repensar o discurso sobre o corpo e estabeleceu a crítica sobre a concepção de corpo centrada em uma racionalidade metafísica travestida de um discurso moral e, como consequência, a sua difamação, ou seja, o corpo visto como um espaço de menor importância que a razão, tão ressaltada nos propósitos da modernidade.

Para Nietzsche (1997b), a noção de subjetividade se relaciona estreitamente com a dimensão carnal ao se considerar que o ser humano está constituído por forças instintivas, afetivas e, por conseguinte, vitais. Alerta Nietzsche (1997) que não existe nenhuma ideia ou realização que não se vincule ao corpo, o que implica que o corpo não pode ser visto de forma isolada, independente da existência. Com isso, propõe que repensemos o modelo de racionalidade que excluiu o corpo do mundo empírico e que o distanciou da sensibilidade do mundo da vida.

Seguindo este posicionamento nietzschiano, o filósofo Merleau-Ponty (1999) delineia a centralidade do corpo em relação à percepção e propõe que a subjetividade seja considerada como uma consciência encarnada - o ser na existência e o corpo como indispensável ao conhecimento. De tal modo que a noção do corpo-sujeito é colocada em cena e se estabelece mais uma crítica ao formalismo da consciência. O corpo passa a ser sujeito da percepção, cuja proposta é a superação do dualismo cartesiano entre corpo e alma, cujo ponto de partida é a própria existência fenomênica humana. Diz o filósofo que o corpo é o nosso veículo no mundo e não podemos conhecer por meio do pensamento discursivo, temos que viver:

\footnotetext{
Nós reaprendemos a sentir nosso corpo, reencontramos, sob o saber objetivo e distante do corpo, este outro saber que temos dele porque ele está sempre conosco e porque nós somos corpo. Da mesma maneira, será preciso despertar a experiência do mundo tal como ele nos aparece enquanto estamos no mundo por nosso corpo, enquanto percebemos o mundo com nosso corpo. Mas, retomando assim o contato com o corpo e com o mundo, é também a nós mesmos que iremos reencontrar, já que, se percebemos com nosso corpo, o corpo é um eu natural e como que o sujeito da percepção (Merleau-Ponty, 1999, p. 278).
}

Nesta mesma linha, o antropólogo Michael Jackson (1983), movendo-se entre Marcel Mauss e Merleau-Ponty, aponta que o corpo se constitui a si mesmo como um body subject, considerando que o movimento corporal não é uma realidade simbólica, mas sim a própria realidade e que o conhecimento procede da implicação prática e sensual e não de princípios genéricos.

Csordas (1990, p. 5), também influenciado pela proposta merleaupotiana, considera o corpo com o "sujeito da cultura" e cujo conceito de embodiment objetiva 
eclipsar a ideia que o social se inscreve no corpo, ou melhor, o próprio corpo é o campo da cultura. Já o antropólogo português Vale de Almeida (2004) alerta para a necessidade do estabelecimento de pontes entre os modelos linguístico-textuais, simbólicos, cognitivos, fenomenológicos, hermenêuticos ou pragmáticos nos estudos sobre o corpo e ressalta: "Tendo sempre como pano de fundo a experiência da investigação antropológica que tantas vezes nos ensina que é preferível o diálogo entre teorias à luz da diversidade de objectos de análise e experiências de terreno, do que um manual monolítico para a leitura do mundo" (Vale de Almeida, 2004, p.3,).

Vale lembrar que na década de 1930 Marcel Mauss já estava focalizando seus trabalhos sobre o corpo, mas é somente na década de 1970 que este campo de estudo ganhou proeminência e passou ser denominada "antropologia do corpo" com os trabalhos de Mary Douglas, Paul Ekman, Judith Hanna, entre outros.

De lá para cá não seria difícil continuar citando significativos trabalhos neste campo, devido à importância que a temática adquiriu na antropologia e também em outras áreas de conhecimento, como se verifica no próprio convite desta revista, instigando-nos a realizar a interconexão entre corpo, performance e antropologia, sinal evidente de proveitosas possibilidades que esta relação propicia.

Nesta dinâmica, nossa proposta é realizar análises de espetáculos de dança contemporânea brasileira de origem africana, criados por coreógrafos brasileiros, cujas performances corporais constroem escenificações (criações cênicas) com o riso, a ironia e a paródia, provocando discussões e levantando questões de denúncia social.

A primeira obra será do Ateliê de Coreógrafos Brasileiros, criado na cidade de Salvador no ano de 2002. A coreografia analisada se intitula O Samba do Crioulo Doido, do coreógrafo mineiro Luis de Abreu, que atualmente reside em Salvador. É uma composição solo que teve a sua estreia na cidade de São Paulo no ano de 2004. Posteriormente, esta coreografia foi também recriada pelo Ateliê de Coreógrafos Brasileiros para um grupo de dez dançarinos negros.

A seguir, será realizada a análise dos espetáculos artísticos Xirê Obirikiti e Bordados de Corpos, resultantes de pesquisa, criadas e realizados nos anos de 2007 e 2011, respectivamente, pela coreógrafa Maria de Lurdes Barros da Paixão, (Lurdes Paixão), uma das autoras deste artigo.

A atenção será dada à atuação performática como criação de momentos de crítica, mais especificamente a ironia, a paródia e o riso. Momentos estes em que as escenificações citadas convidam a uma análise da inter-relação entre performance, corpo, contexto sociocultural, valores, posicionamentos sociais, modo estético - um diálogo que por si mesmo já é antropológico cujos olhares nos encaminham a transversalidades.

\section{Ainda os ventos da pós-modernidade}

A presença da perspectiva pós-moderna para a compreensão da obra de arte ainda é pertinente nos dias atuais, como sugere Hutcheon (1991). A autora aponta que este fenômeno não deve ser utilizado como um acontecimento intelectual e estético salvacionista da arte contemporânea, mas sim, como uma proposta poética 
cultural articulada com os discursos e práticas sociais vigentes em um dado contexto cultural. Tampouco devemos desconsiderar alguns elementos pós-modernos presentes na arte contemporânea. Hutcheon (1991) também afirma que o fenômeno é estético e intelectual contemporâneo e que a sua existência não pode ser negada, apesar das discordâncias na adoção de sua denominação. Ainda sinaliza que muitos autores afirmam ser de difícil precisão quanto aos seus antagonismos e suas contradições implícitas.

O estudioso estadunidense Paul Fry também faz considerações sobre o pós-modernismo, no âmbito da expressão artística, em uma de suas conferências na Yale University, em 2009, que se coadunam com os princípios norteadores dos estudos acerca da performatividade pós-moderna na dança de origem africana contemporânea. Suas colocações têm como fundamentos as ideias de Deleuze e Guatarri (1995), os quais são também referência nos estudos do autor americano.

Então, pós-modernismo. O que é o pós-modernismo? Creio que sabemos o que é na expressão artística. [...]. De repente, o cenário de New York não é somente uma escola e isso é o sinal. Não é somente um certo tipo de abstração. Não é somente o retorno total ao Realismo, concordado por todos. É uma mescla de tudo (Fry, 2009: online, tradução nossa) .

Igualmente adverte sobre o perigo de se pensar o pós-modernismo como uma escola, uma caldeirão híbrido, onde se misturam diferentes ingredientes com aromas e sabores singulares. Evidentemente, não se pode desconhecer na proposta pós-modernista a tentativa de desconstrução da visão linear da realidade, da contestação à homogeneidade e da crítica às grandes narrativas para abarcar a compreensão da realidade. Com isso, abrange diferentes estilos a partir da ênfase na diversidade da vida, das expressões, das culturas evocando a multiplicidade nas expressões artísticas através de infinitas técnicas e os mais variados materiais e suportes. Inclui também o passado, um elemento importante nas produções afrodescendentes. $O$ passado ancestral como uma referência epistemológica significativa nas produções de origem africana.

Tampouco esqueçamos que o espectador na obra pós-moderna entra e faz intervenções na própria obra, aspecto este bastante utilizado em obras artísticas contemporâneas, cuja participação do outro tem grande importância. Rompe assim com a supremacia da individualidade para a noção de uma construção que inclui o outro. Portanto, uma das posturas mais atraentes da perspectiva pós-moderna é que a mesma se impõe como uma postura auto reflexiva e crítica, principalmente quando propicia a desconstrução de parâmetros como o distanciamento e o individualismo, que serão bastante questionados no momento em que o espectador passa a ter um papel relevante na obra artística.

Neste sentido, consideramos que a ironia, o riso e a paródia são bastante propícios para a integração do outro, do espectador que é convidado à participação. Assim, entendemos ser necessário o estabelecimento de diferenças e intercomunicações entre estas três modalidades, que serão visualizadas a seguir.

${ }^{3}$ So Postmodernism. What is Postmodernism? I think we know what it is in artistic expression. [...]. All of a sudden, the New York scene isn't just one school, and that's the sign of it. It's not just a certain kind of abstraction. It's not just a Wholesale return, agreed on by everyone, to Realism. It's a mixture of everything. 


\section{Deslocando o olhar através da ironia}

A respeito da ironia, Muecke (1995, p.18) tece considerações e levanta os seguintes questionamentos: "o que é a ironia e como ela atua; para que serve e o que vale; de que é feita e como é elaborada; como a conhecemos quando a vemos; de onde provém o conceito e para onde vai". Tais questionamentos direcionam os estudos aqui propostos, pois colaboram no sentido de estabelecer analogias a esses questionamentos no contexto da dança contemporânea.

É um fato o lidar constantemente com a ironia no dia a dia. A mesma é um meio de dizermos, tratarmos e transformarmos as coisas sérias em não sérias e as que não são sérias em assuntos a serem tratados com seriedade, então se pode afirmar que a ironia, a priori, é um meio de deslocar as coisas de um determinado lugar para outro e o deslocamento das coisas é o que provoca e altera o equilíbrio ou desequilibra os acontecimentos.

Nessa perspectiva, a ironia pressupõe um desvio do olhar para as coisas do mundo. Pode-se entender esse desvio de olhar como um tipo de olhar de soslaio, oblíquo, cujos olhos se esguelham para mudar o foco sobre a paisagem e os acontecimentos observados. Isto corresponde, por analogia, às ideias de Calvino (1990) acerca de uma das suas seis proposições para o próximo milênio, a saber: A leveza, de acordo com este autor, significa uma mudança de atitude, de postura com algo que é pesado e continua com seu peso substancial, mas que é passível de tornar-se leve, na medida em que alteramos a forma de lidar com o objeto observado, com os sentimentos, as sensações e as nossas percepções do mundo, da vida e de nossas apreciações e fruições estéticas.

Compreende-se que a ironia em suas provocações, contaminações e reações no espectador nas artes, da cena contemporânea, também é dotada de leveza. As diferentes poéticas artísticas contemporâneas pós-modernas fazem o uso da ironia para falar, provocar, subverter e denunciar as coisas com a seriedade inerente à própria ironia.

Ao observar algumas danças de origem africana, como o samba de roda, por exemplo, constata-se que nesta dança, os gestos, a musicalidade e as letras das músicas possuem um caráter jocoso, que se mistura com o lúdico, e a crítica, num grau de malícia e denúncia de comportamentos e posturas sociais. Vale citar uma estrofe de uma letra de autor desconhecido que diz: "você diz que sabe muito, lagartixa sabe mais; anda de perna pra riba, coisa que você não faz". Este verso associado a diferentes situações da vida cotidiana, das relações de mando e poder entre classes sociais e culturais distintas, denota que o autor compara a sabedoria dos humanos com a da lagartixa e atribui a esta última, mais sabedoria que os homens, pelo fato da mesma andar de pernas para cima sobre a parede, coisa que os humanos são incapazes de executar com a mesma destreza e habilidade.

Pode-se afirmar que nesses versos há uma proposição irônica a que Muecke apud Alavarce (2009) denomina de ironia popular, ou seja, trata-se de uma ironia abstraída e construída a partir das vivências cotidianas. Segundo Alavarce (2009), esse tipo de ironia é a mais simples e não oferece dificuldade de interpretação, no mesmo 
nível de complexidade da ironia literária.

A partir das reflexões de Alavarce, com base nas ideias apresentadas por Muecke (1995), acerca da presença da ironia nas artes não verbais como a música, as artes visuais, a escultura, dentre outras formas de arte, entende-se que a ironia pode também estar presente na dança e essa dança pode ser tão irônica quanto a literatura. Isso porque qualquer espectador da arte com o grau mediano de informação e leitura pode encontrar na dança, na pintura, na escultura, no teatro e nas performances contemporâneas, graus variados de crítica e ironia. Nota-se também que os versos irônicos associados ao corpo dançando e atuando de forma jocosa e debochada, no samba de roda, pode provocar o riso.

A mudança de atitude frente ao fato narrado e/ou vivenciado significa dizer que a ironia recoloca em cena um dado acontecimento e transforma o modo como o mesmo é observado pelos indivíduos. A ironia é propositiva, irreverente, pois convida os indivíduos a desestabilizar suas certezas e suas verdades sobre si mesmo e o seu contexto sócio-histórico-cultural.

\section{A potência subversiva do riso}

Comumente associa-se o riso ao humor, às coisas engraçadas. Também é comum a associação do riso com o prazer sentido com as coisas e os acontecimentos alegres. Nessa perspectiva, o riso é visto como algo inerente ao ser humano. A citação abaixo ratifica estas ideias:

\footnotetext{
A influência de Aristóteles talvez seja a mais marcante na história do pensamento sobre o riso, principalmente no que concerne à consagração de sua definição do cômico como uma deformidade que não implica dor nem destruição. Essa definição, que se acha na Poética, estabelece-se como característica primeira do cômico já na Antiguidade e atravessa os séculos seguintes com soberania. Outra concepção corrente que remonta a Aristóteles é sua definição do riso como especificidade humana (Alberti apud Alavarce, 2009, p.73).
}

De acordo com Lipovetsky (1983) o riso cômico é uma herança cultural humana de diferentes sociedades e isto significa dizer que cada povo cria um mecanismo de construção de sua comicidade em seu contexto sócio-histórico-cultural em épocas distintas. Assim, as características estéticas de natureza grotesca na idade média apresentam um riso transgressor das normas e regras oficiais vigentes. $O$ riso torna-se dissimulado e circunscrito à esfera privada nos bailes e salões da classe social burguesa - o riso da Belle Époque. O riso para alguns críticos do movimento cultural pós-moderno liquefez-se. Uma concepção que corresponde ao conceito de "Modenidade Líquida" do Sociólogo Polonês Zygmunt Bauman. Para Bauman (2001) a Pós Modernidade é líquida, leve, fluída e assim abre espaço para críticas, questionamentos e reflexões.

Nessa perspectiva, a potência subversiva provocadora do riso escoa pelo ralo, mas não se perde, transforma-se e adquire outros contornos. Nas cenas dos espetáculos de humor televisivo feitos para serem digeridos por uma grande massa, cujo objetivo é fazê-los rir de qualquer coisa. Contudo, observa-se que em outros con- 
textos da cena espetacular contemporânea o riso é provocado por meio de ações em que existem zonas de tensão entre o que se vê e quem observa, ou assiste estas cenas. Trata-se então do riso transgressor, subversivo, irônico, paródico que tira o espectador de sua zona de conforto, do estado de apatia do riso para um estado de empatia e apetite para e com o riso, o que corresponde a tornar-se também risível.

Ao começar uma reflexão sobre o lugar do riso na tradição filosófica ocidental, constata-se um paradoxo: o pensamento acadêmico dá prova de uma histórica falta de senso de humor e demonstra uma dificuldade de pensar o riso e o risível como temas relevantes em análises "sérias" de sistemas sociais, políticos ou cosmológicos (Lagrou, 2006, p.3).

A coreografia O Samba do Crioulo Doido, objeto de análise neste escrito, chama atenção por recolocar em cena a potência subversiva e provocadora do riso que alguns críticos afirmam estar desaparecendo na sociedade contemporânea.

Aproximando-se do final da citada coreografia, um dançarino com um pandeiro em suas mãos puxa estrofes do samba de roda baiano e cada dançarino, por sua vez, executa passos de dança desta manifestação cultural fazendo caras e bocas, ora rebolando de forma exagerada, ora arqueando o corpo, abaixando o quadril, dobrando os joelhos e abaixando até o chão, em clara alusão aos dançarinos do controvertido grupo de pagode baiano denominado "É o "Tchan." A dança performática deste grupo é conhecida, popularmente, como a dança da "boquinha da garrafa".

A ação performática dos dançarinos do Samba do Crioulo Doido acontece ao som percussivo das batidas do pandeiro e agrega uma cena em que um dançarino com o microfone passa a ler um texto que descreve uma classificação aleatória de cores, que fazem referência à pele negra assim descrita: vermelho avermelhado, galego agalegado, cor de mula, cor de jambo, neguinha cor de tifo, cor de burro quando foge, cor de canela, corpo colorido, dentre outras nominações. Em resposta ao texto, os dançarinos que rebolam respondem a algumas dessas nominações como se estivessem confirmando sua presença na cena e na listagem didática das cores de suas peles.

Na escenificação descrita acima, a reação do público é de riso e gargalhada. Isto conduz para alguns questionamentos acerca do riso nas cenas de dança pós-moderna e sua relação com a ironia e a paródia. Neste sentido, pode-se afirmar que este elemento está presente nas cenas de dança, já descritas. O riso que deriva de uma performatividade ancorada em questões de ordem política, social, cultural e ideológica.

A dramaturgia coreográfica do Samba do Crioulo Doido emerge visivelmente de conteúdos e de situações vivenciadas por indivíduos, homens e mulheres negros que há muitas décadas têm denunciado e exposto todo tipo de preconceito e de exclusão social a que são submetidos na sociedade civil brasileira. Questões polêmicas, complexas, sérias, assumidas e tratadas artisticamente de forma irônica e paródica, sem, contudo, deixar escoar pelo ralo o potencial subversivo do riso, do humor escrachado, mas não execrável que se faz risível não pela ausência de uma performance crítica, analítica e reflexiva, mas, sobretudo pela sua exegese.

Na performance de Luis de Abreu fica bastante evidente que o corpo é o cam- 
po da cultura, como aponta Csordas (1990). Tanto o corpo pode expor uma série de preconceitos como também desmitificá-los performaticamente. A performance do citado bailarino é um desses momentos de crítica social. A imbricação entre o corpo, performance e dança afrodescendente pode ser um momento de permanência do convencionalismo caduco ou de uma significativa ressignificação social. Neste sentido, performatizar criticamente é um momento de se repensar e reconfigurar o que os nossos corpos vivenciam.

\section{A transgressão da paródia}

A paródia, assim como a ironia e o riso tem o objetivo de deslocar o olhar para o que está posto de forma séria e sisuda. Possibilitando, deste modo, novas expectativas e novas estratégias a diferentes saberes e fazeres artísticos, ao estabelecer comunicação com as coisas sérias do mundo. Não apenas de modo contemplativo, mas, sobretudo, de modo provocativo, questionador e transgressor da realidade vivenciada. A paródia também provoca outros modos de relação do indivíduo com os acontecimentos socioculturais. Nessa ótica, pode-se argumentar que se o riso e a ironia subvertem a ordem das coisas, desestabilizam e desequilibram ideologias e posturas dogmáticas vigentes, como também desmascaram falsas verdades, então, com a paródia não poderia ser de forma diferente, pois se sabe que a mesma tem a função de ruptura, de realocação e readequação das ideologias e modelos socioculturais em vigor.

Com base nessas premissas, a paródia e o parodiador apresentam respectivamente inovações no contexto cultural onde se insere, ou seja, a paródia e o parodiador criam novas versões para as histórias sociais e as verdades existentes. O parodiador dá novo sentido a essas verdades, as subverte, as questiona e as denuncia de um jeito singular e apropriado ao seu tempo e lugar.

Nesta recusa em aceitar os modelos literários vigentes ou os mitos, ou os proce-
dimentos, ou melhor, tudo aquilo que compõe o acervo cultural de sua época, o
parodiador está denunciando a sua preocupação com os elementos que servem a
esta estrutura já esgotada, que é preciso esvaziar, para poder preencher com algo
novo. Por vezes a paródia fica camuflada sob certos tipos de disfarces, nos quais
não percebemos, de imediato, a intenção do autor. Geralmente, o recurso de falar
de outras épocas, de culturas ultrapassadas, é empregado como crítica à ideologia
vigente em sua própria época (Aragão apud Alavarce, 2009, p.59).

Neste sentido, O Samba do Crioulo Doido apresenta características da paródia que convém analisar: no inicio da coreografia, na versão criada para o ateliê de coreógrafos brasileiros com dez dançarinos negros, dos quais apenas um intérprete é do sexo feminino, todos estão nus e localizados no fundo do palco. O cenário é feito nas cores verde e amarela com o símbolo da bandeira brasileira e os intérpretes performam com botas de salto alto na cor prata. Os dançarinos executam movimentos ondulatórios, sinuosos, polirrítmicos, policêntricos e repetitivos. Características presentes na estética das danças de origem afro-brasileira. Os passos executados e as botas altas na cor prata remetem à estética carnavalesca do samba das escolas do Rio de Janeiro. Igualmente se observa que, embora os corpos dos dançarinos estejam 
desnudos, a ênfase não recai sobre a nudez dos corpos, mas nos movimentos sinuosos, ondulatórios, com destaque para o rebolar dos quadris. Não há na coreografia o apelo erótico-sensual, comumente explorado nas temáticas e danças de origem negro-africanas.

Acredita-se que isto se deve à zona de tensão criada na dramaturgia corpo-cênica coreográfica que, embora recoloque em cena corpos nus, jovens, fortes e belos, ao mesmo tempo, desconstrói o estereótipo e o apelo sexual que a cena poderia provocar, por meio de recursos sonoros em que a voz da cantora Elza Soares atravessa a cena assim cantando: "a carne mais barata do mercado é a carne negra", estrofe repetida na cena, com pausas intercaladas, combinadas com a execução de formas corporais estáticas realizadas pelos dançarinos.

Os corpos em pausa se comportam como se fossem fotografados em close e em pose se deixam fotografar. Sempre que a voz da Elza Soares adentra na coreografia é como se a mesma atravessasse os corpos nus, expondo-os mais e mais na cena, deixando-os em aberto e dilatando cada vez as subjetividades inscritas naqueles corpos. Corpos expressivos, dançantes, encarnados na carne vida e viva que por sua vez provoca o deslocamento do olhar para outras paisagens e para outros devires. Corpos desnudos subversivos de si mesmos e de suas histórias enviesadas, estereotipadas que ao dançar revelam-se, afirmam-se.

Ao afirmar-se também se nega, nega e renega a condição de que "a carne mais barata do mercado é a carne negra." Isto quer dizer que quando o corpo rebola na dança do Samba do Crioulo Doido a estrofe da música e a voz da cantora contribui para negar, desdenhar e distanciar o olhar do espectador do signo referente: samba que remete aos desfiles das escolas de samba do carnaval do Rio de Janeiro, ao povo negro, ao corpo negro, à sensualidade da mulata e seu erotismo, dentre outros aspectos. Uma escenificação que instaura e propõe diferentes discursos corporais performáticos na cena de dança.

Neste prisma, a opção de estudos acerca da ironia, do riso e da paródia nas criações em dança se deve à constatação de que as coreografias no contexto histórico da dança, suas dramaturgias clássicas e modernas possuem forte densidade dramática, construídas a partir das diferentes dimensões humanas, em que o ritual e o mitológico perpassam as relações estabelecidas pelos indivíduos e a sua cultura. Além disso, a dança também constrói narrativas que apelam para os problemas existenciais humanos, em sua dimensão trágica. Esses aspectos, além de chamar a atenção para a densidade e carga dramática, inserida historicamente nas coreografias em dança, também se referem sobre a ausência, ou pouca ênfase dada ao humor, ao riso cômico, à paródia e à ironia nas criações em dança contemporânea.

O riso, assim como a ironia e a paródia, é objeto de análise na cena de dança visando observar de que forma o coreógrafo e ou intérprete-criador lida com essa tríade em sua criação coreográfica. Alavarce (2009) afirma que há uma proximidade entre a ironia, o riso e a paródia devido ao fato dessa tríade compartilhar funções, as quais questionam as certezas, as verdades absolutas e as divisões entre o certo e o errado, cuja consequência é o surgimento de uma zona de tensão e de elementos desiguais tanto na ironia quanto no riso e na paródia. 


\section{A subversividade da performance corporal}

Nessa perspectiva, observa-se que a matriz estético-cultural negro-africana está presente na obra de Luís de Abreu, porém o coreógrafo a trata de forma diferente do habitual com que o corpo do dançarino negro é tratado nas coreografias de dança afrodescendente, ou seja, Abreu não coloca ênfase ao que Conceição (2005, p.2) denomina dos três " $\mathrm{L}$ " atribuídos à imagem do negro na mídia: o lúgubre, o lúdico e luxurioso 4 . De tal modo que a obra de Luís de Abreu se distancia e não é vista sob o prisma do estereótipo de algo que é exótico, folclórico e sensual.

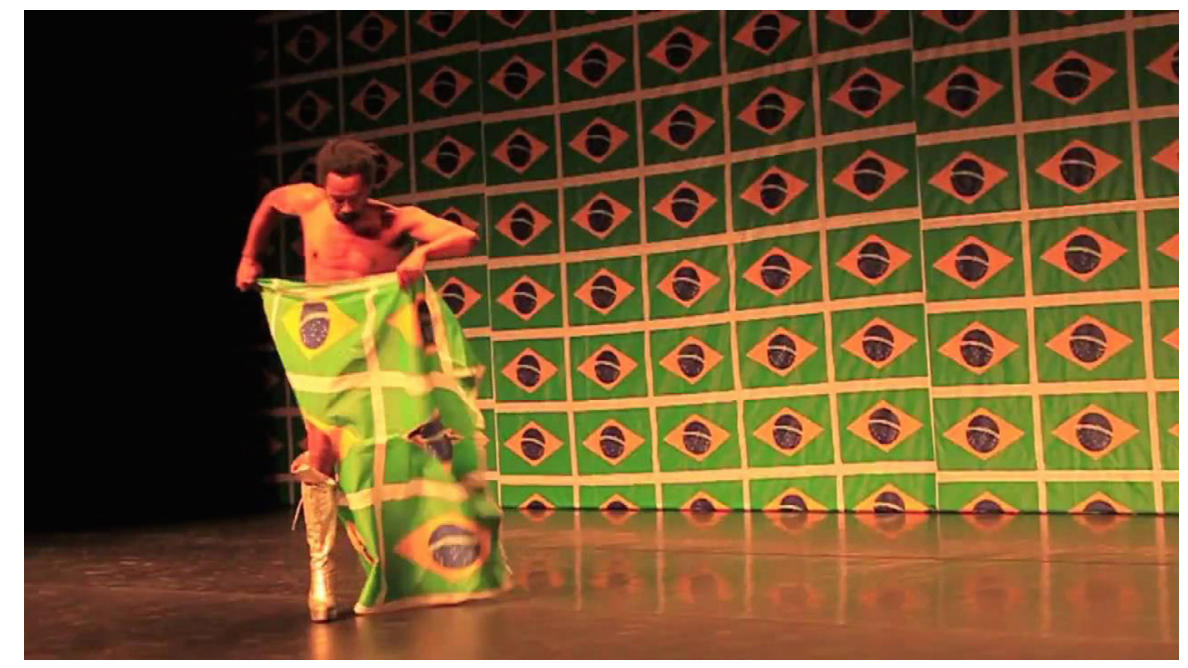

Imagem 1 - Luis de Abreu em O Samba do Crioulo Doido

Fonte < https://www.google.com.br/search?q=core\%C3\%B3grafo+Luis+de+Abreu+em+salvador>

Abreu subverte os três "L" em sua obra quando desloca o olhar do espectador para além das imagens de corpos negros estereotipados e traz à superfície corpos em uma performance que trabalha com elementos afrodescendentes. Deixa visível que a densidade da obra coreográfica é aumentada, acrescida e que, por analogia, corresponde ao que Abreu denomina de lente de aumento quando coloca em suas obras coreográficas posições que o público possa perceber como questões de gênero, raça, nacionalidade, sexualidade, dentre outras, integradas à própria performance. Este posicionamento é uma tentativa de desconstruir o olhar "viciado" e acostumado a ver apenas algum tipo de apelo sensual e erótico do corpo negro que dança.

O sociólogo-antropólogo Marcel Mauss (1979), que foi um dos precursores sobre o estudo do corpo, construiu a noção de "homem total" referindo-se às três dimensões irredutíveis e intrínsecas do indivíduo: o corpo, a consciência individual e a consciência coletiva. Uma visão de ser humano não separada em faculdades, coisificado, limitado a objeto de conhecimento, defendendo, então, um ser humano completo e total. Uma visão de integração entre os aspectos biológicos, psíquicos e socioculturais e, portanto, uma concepção que ainda continua bastante atual.

Nesta esteira da inseparabilidade encontramos o pensamento de Scheper-Hughes e Lock (1987, p. 7) que assinalam a existência de três corpos, o individual, o so-

${ }^{4} \mathrm{O}$ termo lúgubre se relaciona a acontecimentos policiais; lúdico a estereótipos das "alegres" festas nacionais; e luxurioso a sexualidade. 
cial e o político, demonstrando que a dimensão corporal é uma interconexão entre as três dimensões, que podem ser definidas, mas que não podem existir isoladamente. Mas o que isso tem a ver com a performance de Luis de Abreu?

Quando o bailarino-criador exibe sua obra discutindo no próprio corpo questões de gênero, preconceito, exploração simbólica, rompendo um modo de colocar certos temas para discutir, criticar aspectos sociais, ele sobe ao palco com a noção de ser humano sem as fissuras de um pensamento que tentou isolar os sentimentos da razão, o corpo e consciência, como criticou Mauss no início do século passado. Abreu veste a crítica em seu próprio corpo, que integra as dimensões que Scheper-Hughes e Lock apontam, o individual, o social e o político. É o bailarino inteiro que se representa a todos em sua dinâmica de contestação política.

O seu corpo também nos abarca. Estamos representados em seu corpo, o corpo individual e social ao mesmo tempo, que faz a crítica com subversão, mas com leveza que deixa espaço para o riso - o riso que propicia o pensar. Ele não cria um espetáculo para seu próprio prazer de exibir-se diante de uma plateia, o seu corpo em cena requisita o mais importante de sua produção: a participação do outro para reconstruir com ele o modo de pensar coletivo impregnado de negações, de limitações, de separações, ainda tão vigentes em nossa sociedade.

Além disso, a dança do samba na criação de Luis de Abreu, tanto em sua composição solo como na recriação coletiva, posterior, recebe tratamento ético e estético performático que denota o caráter crítico, irônico e parodiador de como o artista trata o samba. Contudo, Abreu apresenta uma proposta estética que se opõe ao estereótipo do corpo e da dança de origem africana vistos como produtos Made in Brazil, ou seja, como produtos eróticos e exóticos tipo exportação a serem consumidos pelo mercado do entretenimento turístico que exalta o erotismo do corpo e da dança de origem africana, especialmente com a finalidade de comercialização para o turista estrangeiro.

A análise desta obra coreográfica evidencia como o coreógrafo e intérprete transita e lida com elementos da cultura, tradição e ancestralidade numa perspectiva conceitual e estética da arte e da performance em dança contemporânea. Assim, as três características conceituais e estéticas, a paródia, a ironia e o riso confirmam as apropriações e contaminações destas características presentes em maior ou menor grau na criação coreográfica O Samba do Crioulo Doido.

\section{Xirê Obirikiti e Bordados de Corpos}

Quanto aos espetáculos artísticos Xirê Obirikiti (2007) e Bordados de Copos (2011), de Lurdes Paixão, exemplificam também a utilização da ironia, do riso e da paródia e sua apropriação estética na composição coreográfica. Ambas as coreografias trazem estas características para o contexto da criação e ressignificação estética dos elementos sígnicos e simbólicos da dança afro-brasileira.

A coreografia Xirê Obirikiti - a dança da roda ritual, criada inicialmente numa versão solo, no ano de 2007, coloca em cena uma dançarina intérprete-criadora dizendo frases ao mesmo tempo em que seu corpo gesticula de forma diferente e desconexa do discurso proferido. O texto extraído e adaptado do imaginário popu- 
lar aludia aos ditos e expressões populares empregados pelos ancestrais africanos, quando chegaram ao Brasil. Expressões estas que na atualidade ainda são repetidos por seus familiares afrodescendentes. As cenas realizadas empregavam as seguintes expressões: "Louvado seja a fartura", "A galinha pulou", "fulano está se passando de pato para ganso" e "Misericórdia." A utilização dessas expressões ditas de forma séria, porém irônica, no contexto cênico-dramatúrgico-coreográfico possibilitou a ressignificação estética e simbólica desses elementos na cena de dança.

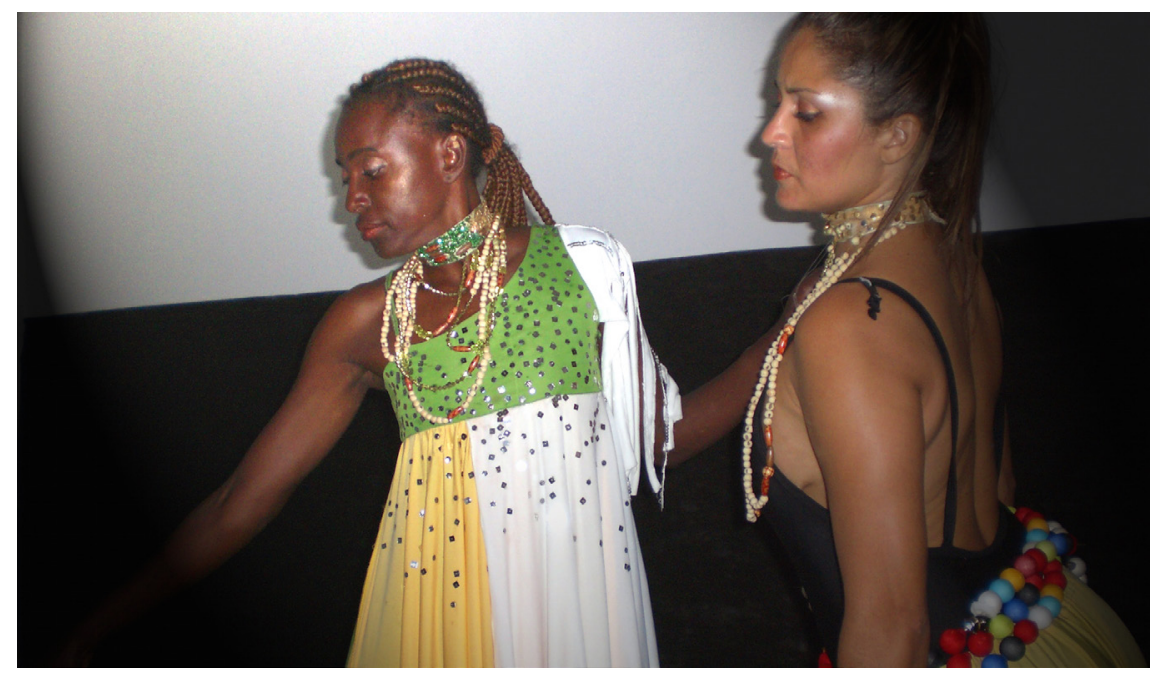

Imagem 2 - Cena de Xirê Obikiriti. Fonte: Lurdes Paixão, 2007

Vale citar as impressões que a dançarina obteve acerca da recepção estética dessa cena pelos espectadores. A mesma relata que quase perdeu a concentração, em cena, por conta do riso que provocava nos espectadores ao enunciar as expressões citadas. Ela não entendia o que havia de engraçado nessas expressões. Eram ditas com ênfase na seriedade dos gestos realizados de forma contida e em expressões corporais sisudas. A dançarina não entendia o que de engraçado perpassava a postura e o comportamento irônico e parodiador de suas ações, capaz de provocar o riso nos espectadores.

Após a apresentação da coreografia a dançarina conversou com parte do público presente e a mesma pôde constatar que, embora as suas ações de características irônicas e paródicas fossem feitas sem a intenção de provocar o riso nos espectadores, pois eram feitas de forma séria, ainda assim o público ria porque compreendia o tom jocoso e irônico das ações da dançarina - o que demonstra relações de afeto e de empatia do público com a cena. Os espectadores compreenderam as intenções e sutilezas da proposta que fazia alusão a um comportamento estereotipado e o deslocava de seu contexto usual, rumo a outros contextos, a outros olhares e formas de recepção.

No espetáculo Bordados de Corpos (2011), criado para cinco intérpretes-criadores, vários poemas do poeta Mato Grossense Manoel de Barros (2000) foram adaptados. A coreografia utiliza recortes e fragmentos de versos do poeta adaptando-os à dramaturgia e à poética coreográfica, ao mesmo tempo em que denuncia o autoritarismo, as perseguições e os tratamentos excludentes dado pela cultura local 
às pessoas que chegam de outras localidades e de diferentes nacionalidades, numa proposição estético-cênico-coreográfica em que a ironia, a paródia e o riso são incorporados à dramaturgia corpo-cênica.

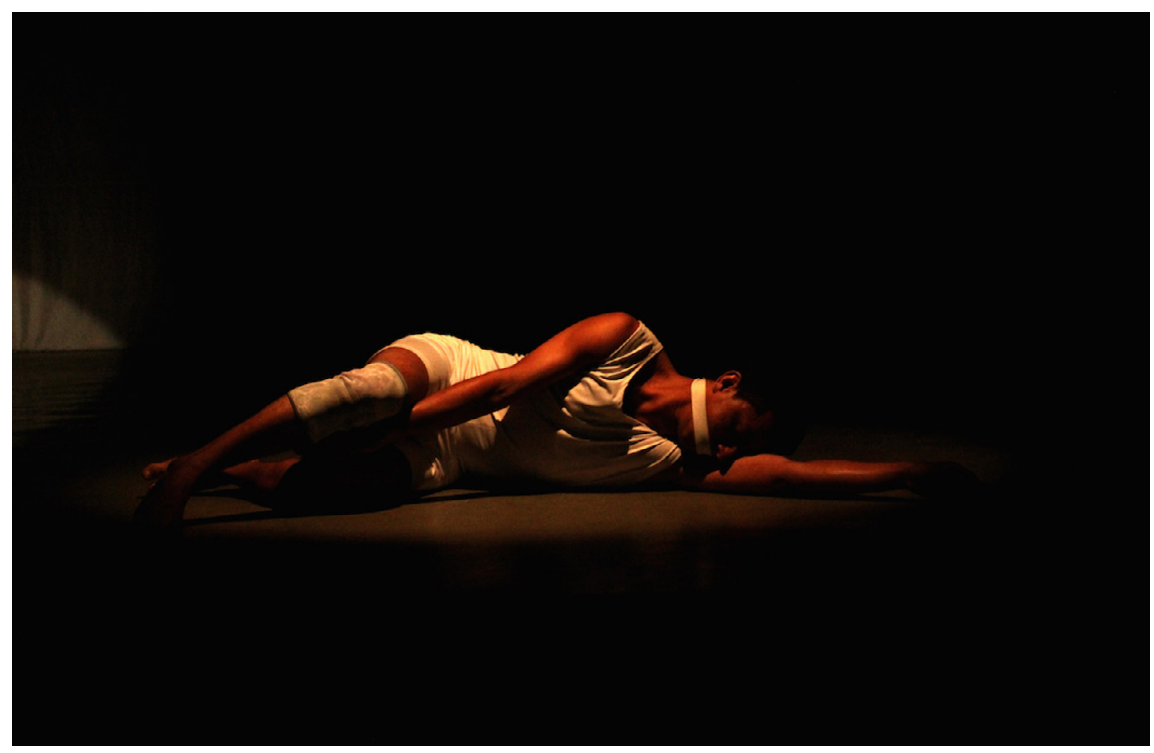

Imagem 3. Cena de Bordados de Corpos. Fonte: Rayane Azevedo, 2011

Ainda neste espetáculo, os dançarinos gesticulam e pronunciam frases desconexas. A música ou um objeto cênico utilizado, a exemplo de tecidos amarrados nos rostos dos bailarinos e em suas bocas em alusão à cegueira e o silêncio dos indivíduos diante de diferentes situações, que imobilizam e impedem uma ação efetiva de contestação e transgressão, frente a imposições arbitrárias de mando e do uso da força, e do poder dominante.

O uso dos tecidos, respectivamente nos olhos e nas bocas dos dançarinos, foi utilizado concomitante com frases ditas pelos mesmos associados à ação corporal de retirada dos tecidos, tanto da boca quanto dos olhos dos performers. O grupo de dançarinos que estava com os olhos vendados com tiras de tecidos, na cor preta, posiciona-se atrás dos dançarinos que estavam com as bocas amarradas com uma tira de tecido, na cor vermelha.

Os dançarinos com os olhos vendados pronunciam a seguinte frase: "quem cala consente" em tom provocativo e ameaçador dirigido aos dançarinos que permaneciam com as bocas amordaçadas e que, ao sentirem-se provocados, arrancam o tecido preso de suas bocas. Em seguida se prostram atrás dos dançarinos com olhos vendados e dizem a seguinte frase: "o maior cego é aquele que não quer ver" ao mesmo tempo em que arrancam as vendas dos olhos dos dançarinos, de forma abrupta.

Nesta cena coreográfica pode-se observar que houve um deslocamento, uma troca de lugar das coisas ditas e das ações corporais, tanto dos dançarinos, de olhos vendados, quanto os que estavam com a boca amordaçada. Observa-se que ambas as ações são irônicas, criam rupturas e desequilíbrios que, por sua vez, também instauram um jogo parodiador que induz o espectador a refletir sobre o silêncio e a mudez enquanto formas de se posicionar ou não se posicionando.

A cegueira como uma opção para não ver ou só enxergar o que é conveniente 
num determinado contexto social. A boca amordaçada e os olhos vendados dos corpos dos dançarinos denunciam e provocam outros olhares acerca das escolhas que somos capazes de fazer diante de situações conflituosas, ameaçadoras e de sobrevivência. A venda nos olhos e o pano amarrado na boca dos performers são ações que caracterizam o que o sujeito da ação quer negar. Neste movimento dual de negação e afirmação os intérpretes instauram uma zona de tensão que propicia o riso cômico, o riso sério e o riso irônico. Diante disso, enfatizava-se a crítica irônica aos fatos e aos acontecimentos vivenciados pelos dançarinos, capazes também de afetar e estabelecer relações análogas com o espectador.

Ainda em Bordado de Corpos uma das dançarinas pergunta ao público o que era misturar "Lé com Cré"5 e no final do espetáculo devolve a pergunta novamente para o público. Outra dançarina pergunta ao público quem era mais sábio o homem ou a lagartixa, em alusão à letra do samba de roda de autor desconhecido, anteriormente citado. Também um dançarino indaga ao público se os mesmos "sabiam colocar aflição numa pedra" e se sabiam "pegar mosca no hospício com a intenção de banhá-las", em alusão aos escritos poéticos de Manuel de Barros presente em sua obra intitulada $O$ livro das Ignorãnças.

Todas essas perguntas tinham o objetivo de inquietar o espectador. Tratava-se apenas de uma provocação e não se esperava que o público devesse responder às perguntas feitas pelos dançarinos, porém esperava-se que pudessem refletir sobre $o$ jogo que foi proposto na cena de dança.

O espetáculo também fazia alusão aos comportamentos aceitos como politicamente corretos na sociedade que endeusa alguns indivíduos, geralmente os que se comportam de acordo com as regras sociais e os valores sociais impostos por um grupo que se coloca como hegemônico. Um comportamento que pode chegar a demonizar outros sujeitos que se rebelam e questionam os padrões sociais e culturais vigentes socialmente.

Os dois espetáculos propostos articularam questões conceituais e estéticas da arte pós-moderna, embora a autora, na época, não tivesse a pretensão de realizar discussões aprofundadas sobre esses conceitos e os seus efeitos na produção estética contemporânea na dança, especificamente no âmbito da dança afrodescendente.

A partir dessas criações, a autora Lurdes Paixão expressa que o seu sentido crítico foi aguçado em torno dos preconceitos e interdições e os porquês que impedem a articulação dos conceitos e referências estéticas da arte contemporânea de se tornarem visíveis, discutíveis e amplificados na chamada dança pós-moderna brasileira, no mesmo nível de outras formas de arte, como por exemplo, o teatro.

\section{Repensando a dança de origem africana}

Elementos ressignificados e recriados na cena de dança contemporânea dão origem ao que denominamos de dança brasileira afro-brasileira pós-moderna. Entretanto, se reconhece que há uma resistência ideológica em creditar e nominar as

\footnotetext{
5 "Lé com Cré" expressão popular dita de forma irônica sobre coisas ou acontecimentos que não têm uma explicação coerente, que são confusos, ou seja, não dizer coisa com coisa.
} 
criações na dança cênica afro-brasileira e suas ressignificações estéticas nos estudos dramatúrgicos em dança. Estudos estes que possam apoiar uma reflexão crítica acerca de uma dança de origem africana na cena contemporânea.

Comumente, os coreógrafos desta modalidade de dança recolocam os elementos simbólicos e sígnicos originários africanos em suas criações coreográficas, sem, contudo, observar que essas danças têm permanecido prisioneiras dos signos referentes de origem e não propiciam abordagens críticas que ultrapassem e/ou dialoguem com outros elementos do contexto sociocultural. Com frequência, certos espetáculos cênicos repetem a simbologia original afro descendente sem a realização de deslocamentos que possibilitem outras configurações criativo-críticas. Tampouco se observa a utilização do riso, da paródia e da ironia, ficando mais voltados para a repetição numa tentativa de trazer ao palco, de uma forma mimética, uma dança popular como o Maracatu, por exemplo, resultando em uma clonagem deslocada do contexto e sem adensar a perspectiva critico-histórico-cultural.

Um segundo aspecto diz respeito à forma como os coreógrafos se apropriam das danças originárias da tradição religiosa afro-brasileira. Observa-se que o olhar dos coreógrafos sobre elas quase sempre se referem à gestualidade simbólica, que possuem sentido prévio e com ênfase no elemento dramático associado à função ritual, embora as coreografias se apresentem deslocadas de seu contexto e de sua função sagrada. Fato que perturba o estado de presença, problematizando a questão entre o estado ritual e o estado cênico.

Segundo Gumbrecht (2010) a arte contemporânea oscila respectivamente entre efeitos de produção de sentido e efeitos de produção de presença. Com isto queremos dizer que há formas distintas de se tratar a criação artística, ou seja, pode-se criar uma obra coreográfica mais presa ao signo referente, cuja ênfase dada ou os seus objetivos estão voltados para produção de sentido.

A produção de sentido reafirma a necessidade de explicação e interpretação dos símbolos e signos que já se encontram presentes na obra. Também existem outras criações artísticas em dança, que intencionalmente se distanciam do signo referente e apresentam novas possibilidades de apreciação estética a partir daquilo que ela apresenta em ausência de significação, ou seja, em sua produção de presença. Pode-se dizer que estas criações estão mais abertas em rede de significações. A citação abaixo confirma essa compreensão:

Mas, apesar do princípio de que todos os discursos de autode $\neg$ scrição coletiva contêm elementos de cultura de sentido e de presença, está certo supor que alguns fenômenos culturais (por exemplo os sacramentos da igreja ou a racionalidades de atuais cultos afro-brasileiros) estão mais ao lado da cultura de presença, ao passo que outros (como a antiga política de Roma ou a burocra $\neg$ cia do inicio do império espanhol são predominantemente funda $\neg$ dos na cultura de sentido (Gumbrecht, 2010, p.106).

Um terceiro aspecto é a constatação de que as coreografias propostas com base na ressignificação estética da tradição afro-brasileira não atentarem para o fato de que existem traços e rastros característicos da estética contemporânea pós-moderna na dança, em termos de proposição e de uma reflexão sobre a arte contemporâ- 
nea, seus pressupostos teóricos e princípios estético-criativos.

A dança de origem africana contemporânea deveria estar atenta à elaboração de propostas estéticas baseadas na desconstrução, na fragmentação de modelos de dança pré-estabelecidos, adentrando na incompletude dos fatos cotidianos, nas impermanências dos corpos e dos sentidos, no ir e vir das cidades, nos acasos e no caos organizável e reestruturante da vida na sociedade atual.

Assim, os estudos propostos analisam a produção de efeitos de presença na arte contemporânea e argumenta que as criações coreográficas da dança afro-brasileira contemporânea, originária dos estudos das matrizes gestuais e estético-culturais africanas, deveriam fazer desaparecer dos corpos dançantes a mera repetição da estética das danças de tradição popular e das práticas rituais e litúrgicas das religiões afro-brasileiras.

Com isto, estamos propondo que as mesmas reconfigure, reelabore o signo referente. Que possam ser identificados determinados elementos do samba de roda, do maracatu ou da dança ritual dos orixás, mas que estes estejam reconfigurados permitindo outras leituras, que por certo não causam demérito algum aos referentes originários. Que a transversalidade dos olhares seja permitida através de um olhar crítico, que favoreça a reflexão. A interconexão com outros saberes e com outras propostas também pode permitir a necessária porosidade e amplitude da dança afro-brasileira no contexto contemporâneo.

\section{Considerações finais}

Vivemos um momento em que não podemos mais permitir os discursos isolados, fechados em si mesmos, pois todo o mundo se transformou num caleidoscópio de possibilidades. Quanto mais tivermos a capacidade para estabelecer pontes, enlaces, interrelações entre os conhecimentos mais nos aproximaremos do gozo da fluidez de trilharmos rotas infindáveis, cujos trabalhos podem ser mais porosos e saborosos.

A oportunidade de bordar um discurso com as temáticas corpo, performance e antropologia nos permitiu traçar caminhos que, na verdade, nunca estiveram separados. O que estava cindido era um tipo de olhar/postura que acreditou ser possível hegemonizar as relações, os conhecimentos e vestimos as indumentárias das caixinhas organizadas em disciplinas separadas e estanques. Felizmente a célebre frase "tudo que é sólido se desmancha no ar" se concretizou e os ventos da pós-modernidade chegaram limpando os óculos embaçados com sistemáticas de tantos séculos de domínio de um pensamento que acreditou firmemente na separação. Foi tão firme a crença nas cisões que ainda hoje nos debatemos com as disjunções.

Quando o bailarino-intérprete, em cena, constrói com o seu corpo um discurso crítico sobre injustiças, estereótipos, preconceitos, é um corpo inteiro, plural, interconectado com o contexto local e mundial. No momento da cena ele está rompendo muitas separações, demolindo dualidades e individualidades. A denúncia em seu corpo não é de um indivíduo que denuncia, é um corpo que também é social congregando outros corpos, o meu, o seu, o da gente brasileira ou de qualquer país, pois romper cisões é também abolir fronteiras.

São trabalhos como os de Luis de Abreu e de Lurdes da Paixão que alertam sobre 
aspectos da construção coreográfica e o tratamento cênico de temas de afro-brasileiros convidando a uma perspectiva crítico-criativa para a ressignificação de um modo de ver e fazer sobre os temas afrodescendentes, nas construções cênicas. A Interunião entre corpo, performance e dança tanto pode nos deixar no mesmo ponto, ou seja, na repetição do signo referente e na difusão de preconceitos ou nos permitir reconfigurar os valores de um contexto sociocultural, como demarcam os trabalhos dos dois coreógrafos estudados.

As propostas dos citados criadores-intérpretes demonstram que é urgente a necessidade de se desconstruir parâmetros, ao invés da repetição pela repetição, e que as escenificações sejam veículos de compreensão crítica e que apresentem novas reconfigurações dos códigos de origem, condição necessária para o reconhecimento e respeito desta modalidade artística.

Portanto, o que se almeja neste momento contemporâneo é que produções com elementos de origem africana possam também estar abertas a inter-relações com outros saberes, considerando-se que a interconexão entre os conhecimentos pode permitir o repensar, do que está posto, o que não deixa de ser um exercício que implica na ressignificação e/ou desconstrução de valores vividos nos corpos. O que os autores colocam em relevo é a elaboração de propostas inovadoras através da interconexão entre corpo, performance e escenificação afrodescendente.

\section{Referências}

ABREU. Luiz. O samba do crioulo doido. Disponível em <https://www.youtube.com/ watch?v=6wZWOZASfF4 > ou <https://www.youtube.com/watch?v=MnsV3cJ0EAY>

ABREU, Luiz. Fotografia do autor em cena do espetáculo $O$ samba do crioulo doido. disponível em: <https://www.google.com.br/search?q=core\%C3\% B3grafo+Luis+de+Abreu+em+salvador> Acesso em: 28 set. 2016.

ALAVARCE, CS. A ironia e suas refrações: um estudo sobre a dissonância na paródia e no riso [online]. São Paulo: Editora UNESP; São Paulo: Cultura Acadêmica., 2009. 208 p. ISBN 978-85-7983-025-9. Available from SciELO Books <http://books.scielo.org>.

BAUMAN, Zygmunt. Modernidade liquida. Trad. Plínio Augusto de Souza Dentzien. Rio de Janeiro: Zahar, 2001.

BARROS. Manoel de. O Livro das Ignorãças. São Paulo: Record, 2000.

CALVINO, Ítalo. Seis propostas para o próximo milênio: lições americanas. (Trad. Ivo Barroso) São Paulo: Companhia das Letras, 1990.

CONCEIÇÃO. Fernando. Como fazer amor com o negro sem se cansar. São Paulo: Terceira Margem, 2005.

CSORDAS, Thomas J. Embodiment as a Paradigm for Anthropology. Ethos, v.18, n.1, 
p. 5-47. 1990.

DELEUZE, G. e GUATTARI, F. Mil platôs. v.1. Rio de Janeiro: Ed. 34, 1995.

FRY, Paul. The postmodern psyche. Vídeo-conferência, 2009, disponível em http// www.youtube.com/results? search query=so+postmodernism+paul+fry. Acesso em: 18 out. 2014.

GUMBRECHT. Hans Ulrich. Produção de presença: o que o sentido não consegue transmitir. Tradução. Ana Isabel Soares. Rio de Janeiro: Contraponto, 2010.

HUTCHEON, Linda. Poética do Pós-modernismo: história, teoria, ficção. Trad. Ricardo Cruz. Rio de Janeiro: Imago, 1991.

2000.

Teoria e política da ironia. Trad. Julio Jeha. Belo Horizonte: Editora UFMG,

JACKSON, Michael. Knowledge of the body. Man, v.18, n.2, p. 327- 345, 1983.

JARA, José. Nietzsche, um pensador póstumo: el cuerpo como centro de gravidade. Barcelona: Antropos Editorial: Valparaiso, Universidad de Valparaiso, 1998.

MAUSS, Marcel. Sociología y antropología. 4. ed. Madrid: Tecnos, 1979.

MERLEAU-PONTY, Maurice. Fenomenologia da percepção. São Paulo: Martins Fontes, 1999.

LIPOVETSKY, Gilles. A era do vazio. Lisboa: Relógio D’Água, 1983.

LAGROU, Els. Rir do poder e o poder do riso nas narrativas e performances Kaxinawa. Revista de Antropologia, São Paulo, v.49, n.1, p.55-90, 2006.

MUECKE, D. C. A ironia e o irônico. Trad. Geraldo Gerson de Souza. São Paulo: Perspectiva, 1995. (Debates, 250).

NIETZSCHE, Friedrich W. La genealogía de la moral. Madrid: Alianza, 1997.

Más allá del bien y del mal. Madrid, Alianza, 1997b.

SANTOS, Jair Ferreira. O que é pós-moderno. São Paulo: Brasiliense, 1987.

SCHECHNER, Richard. Performance studies: an introduction. London: Routledge, 2006.

SCHEPER-HUGHES, Nancy; LOCK, Margaret $M$. The mindful body: a prolegomenon to future work. Medical Anthropology Quarterly, New Series, v.1, n.1, p. 6-41, 1987. 
TAMBIAH, Stanley Jeyaraja. The magical power of words. Man, New Serie, v.3, n, 2, p.175-208, 1968.

TURNER, Victor W. From ritual to theatre: the human seriousness of play. New York: PAJ Publications, 1982.

The anthropology of performance. New York: PAJ Publications, 1987.

VALE DE ALMEIDA, Miguel. O corpo na teoria antropológica. Revista de Comunicação e Linguagens, Lisboa, n.33, p.1-25, 2004.

Acesso em: 10 maio 2016

Recebido em: 11/10/2016

Aprovado em: 14/06/2017 